\title{
Language matters in a pandemic
}

\author{
Do you 'beat' or 'treat' a virus infection? Are you strong if you survive SARS-CoV-2 but weak if you don't? Language \\ matters if we are to galvanize people to follow public health guidance during the COVID-19 pandemic.
}

A $t$ the end of January 2020, the World Health Organization (WHO) issued a statement ${ }^{1}$ that the SARS-CoV-2 outbreak was a public health emergency of international concern. In early March 2020, when the global caseload stood at 100,000, guidance $^{2}$ from the WHO was clear: countries should stop, contain, control, delay and reduce the impact of SARS-CoV-2. But not all countries heeded this advice.

Amid growing consternation at the spread of the virus and the severity of the symptoms, the language changed. A pandemic ${ }^{3}$ was declared by the WHO in mid-March 2020. The use of this word was important. A previously unknown virus was being transmitted in multiple countries simultaneously, and this was the first pandemic caused by a coronavirus. The word 'pandemic' conveys a sense of danger that should have garnered action from all countries at every level. At that point, Dr Tedros Adhanom Ghebreyesus, the Director-General of the WHO, pointed out that "all countries can still change the course of this pandemic" if they "detect, test, treat, isolate, trace, and mobilize their people in the response". The WHO's language was stepped up to be much more specific about the country-level actions required to alter the progression of the pandemic.

There remains a set of simple measures that each of us can adopt in our daily lives to help control infection rates: social distancing, social isolation for the vulnerable, mask wearing and hand washing. Increasingly these simple actions have been blurred by muddled messaging as governments try to navigate towards a 'new normal'.

The clarity of messaging has stuttered as the pandemic has progressed. For example, in the United Kingdom, should we stay two metres apart or one? Should we work from home or go to work? Should we follow the 'rule of six', stay in a bubble or 'eat out to help out'? Not to mention the stunningly vague slogans 'stay alert' and 'hands, face, space' - which should, of course, be 'space, face, hands'. These ever-changing messages, slogans, buzzwords and clickbait continue to deflect attention from failures at a basic level to control infection rates. These include announcements of 'moonshot' ${ }^{\text {'4 }}$ and 'world-beating' plans for mass testing, when tests were in fact unavailable for many days owing to systematic failures to cope with demand. Further, to offset the unfair use of an algorithm that moderated teachers' predictions and awarded pupils with vital exam results largely based on which school they attended, Boris Johnson trumpeted that a 'mutant algorithm' was the problem. So-named to imply that the algorithm itself had changed in some way, this detracted from the reality that the algorithm approved by his government was not fit for purpose and was unjust.

Language matters in public health. It matters because the goals of any public health campaign must be clearly defined, especially when the campaigns include measures that limit liberty, damage the economy and change our way of life. Powerful language can be used to motivate action, and war analogies have somewhat inevitably come to the fore during this pandemic. Leaders around the globe have identified SARS-CoV-2 as a common enemy that we can beat. President Emmanuel Macron of France, for example, said that his nation "was at war with an invisible, elusive enemy."

Whilst there is little doubt that war analogies can be helpful in explaining why extreme measures such as isolation and social distancing are needed, wars drag on over time and the analogies wear thin. A cancer diagnosis often results in the use of battle metaphors that are similar to those now being espoused about SARS-CoV-2. One study found that the use of battle analogies undermines cancer treatment and can deter those without cancer from adopting health behaviours that could reduce their risk of cancer ${ }^{5}$. Importantly, the authors found that using war metaphors can produce fatalistic responses and can result in surrendering behaviours. These types of analogies might conceivably lead to individuals feeling that death is inevitable no matter what they do, and so perhaps they should do what they want. This is most certainly not what is needed in a pandemic, when the actions of individuals are of paramount importance to infection control.

Using the language of war in a pandemic also reduces those who succumb to infection as 'the weak' and lauds those who recover as 'the strong. SARS-CoV-2 infection results in a wide range of symptoms that are more severe in the elderly, in those with underlying conditions, in the poor, in those living in deprived areas and in specific Black, Asian and minority ethnic communities. SARS-CoV-2 can also result in long-term chronic symptoms in around $20 \%$ of cases. Stigmatizing all of these people as weak is patently divisive and wrong.

This misuse of language has recently escalated. To be precise, the language and imagery that some global leaders are using during this pandemic is boding ill for global efforts to control it. Political interests of leaders who have enormous global reach are poised to confuse and dilute crucial public health messages.

We live in an age of rolling news and social media, where language matters more than ever. A single statement by a powerful politician can be viewed by millions upon millions of people in every country around the world. One powerful politician who understands very well how to use language is President Donald Trump. Having eschewed mask use and repeatedly played down the pandemic during a pivotal re-election year, President Trump became infected with SARS-CoV-2. He was whisked off to receive the best care available but chose to leave hospital after just three days, and returned to the White House under the gaze of the world's media.

The stage-managed return to work included imagery of him saluting Marine One and whipping off his mask despite still being infectious. "Don't let it dominate you, don't be afraid of it, you're going to beat it," 6 he declared. "I know there's a risk, there's a danger, but that's OK... I stood out front. I led." Since then, he has described his infection as "a blessing from God", failed to isolate and returned to work in the Oval office in a show of strength. This combative language and defiant behaviour serve to promote the view that the COVID-19 pandemic can be readily overcome with available measures. The image of strength seems designed to undermine the simple public health measures he could instead have chosen to support. 
In a Perspective ${ }^{8}$ by Habersaat et al., a set of behavioural experts convened to delineate ten considerations for effectively managing the COVID-19 transition towards a new normal. With regards to language, they assert that "the aim should be to highlight the gains that can be made from engaging in target behaviours and activate the internal moral compass that renders personal rewards less important than benefits to others".

Many leaders understand the importance of imagery and language that supports public health directives. Marcelo Rebelo de Sousa, the President of Portugal, was pictured $^{9}$ out shopping in a mall, in a mask, on his own. The pictures went viral and reinforced the public health message to wear a mask. Angela Merkel kept her messaging simple and accurate, saying recently ${ }^{10}$ "it is serious. As serious as it ever was."

Effective communication is crucial for the success of public health measures to tackle COVID-19. Politicians, celebrities and influencers who use inflammatory language for personal gain are impeding preventive measures against COVID-19. We call on all of our authors and readers to call out misinformation and challenge the misuses of language that stand in the way of pandemic control.

Published online: 21 October 2020

https://doi.org/10.1038/s41564-020-00812-9

References

1. WHO Director-General's statement on IHR Emergency Committee on Novel Coronavirus (2019-nCoV). World Health
Organization https://go.nature.com/2SFj3Bv (2020).

2. WHO statement on cases of COVID-19 surpassing 100,000 World Health Organization https://go.nature.com/2GNvB7k (2020).

3. WHO Director-General's opening remarks at the media briefing on COVID-19 - 11 March 2020. World Health Organization https://go.nature.com/3dfOaNi (2020).

4. Shearing, H., Nevett, J., Scott, J. \& Collerton, S. UK PM sets out 'moonshot' plan for mass testing. $B B C$ https://go.nature. com/2SFjfkd (2020).

5. Hauser, D. J. \& Schwarz, N. Health Commun. 35 1698-1704 (2020).

6. Trump says not to fear Covid-19. Do Americans agree? $B B C$ https://go.nature.com/2SSlkcw (2020).

7. Cathey, L. 'I had to do it': Trump suggests he got virus as act of political courage. $A B C$ News https://go.nature.com/3jWbWkd (2020).

8. Habersaat, K. B. et al. Nat. Hum. Behav. 4 , 677-687 (2020)

9. Mitchell, D. Portugal's President de Sousa pictured shopping in a local supermarket, during Coronavirus crisis, like any normal citizen and it has gone viral. EuroWeekly https://go.nature. com/34Fhzg3 (2020).

10. Coronavirus: Germany's Angela Merkel warns of hard months to come. $D W$ https://go.nature.com/34JTJQi (2020). 